\title{
Using Storytelling Technique to Improve Karonese and English Language Learning at Students' Sunday School at Gereja Batak Karo Protestan (GBKP)
}

\section{Sri Ninta Tarigan}

Pendidikan Bahasa Inggris Universitas Prima Indonesia

\section{Abstract}

Storytelling is the way to share the story sometimes with improvisation, theatrics, or embellishment. This technique was giving many contributions to students to learn Karo and English. The objective of this research is giving contribution to students to speak Karo and English Language at Gereja Batak Karo Proteston (GBKP). The material

Corresponding Author: Sri Ninta Tarigan srinintatarigan@unprimdn.ac.id

Received: 13 March 2018 Accepted: 10 April 2018 Published: 19 April 2018

Publishing services provided by Knowledge E

(c) Sri Ninta Tarigan. This article is distributed under the terms of the Creative Commons

Attribution License, which permits unrestricted use and redistribution provided that the original author and source are credited.

Selection and Peer-review under the responsibility of the AICLL Conference Committee.

\section{G OPEN ACCESS} was used by two languages. They were Karo and English. The research used action class research in finding research problem. The speaking test result in cycle two explained that the students' got good progress in Karo and English. The instrument used pre-test and post test. The data was taken by observing, field note and interview. The population was 160 students and 20 students as a sample. There were divided into three classes. They are Children, Youth and Teen Class. The location of this research was in GBKP Mekatani in Jalan Mekatoni Marindal Kecamaton Patumbak. The result of this research was found those 13 or $65 \%$ students improve their English Language and 7 or $35 \%$ was not improve their Koronese Language. It meant that there was improvement in English language learning in GBKP.

Keywords: storytelling, Karonese, English, language, learning

\section{Introduction}

GBKP stands for Gereja Batak Karo Protestan. This is a tribe church. Most of the comunity was Karonese. The centre of GBKP is in Kabanjahe Karo Regency. It could devided into many Parts. One of this is GBKP Mekatani. It was located on Jalan Mekatani. As usuall, here the ceremony diveded into two ceremonies. Adults' and Childrens' ceremony. Here the writer want to focus on children ceremony or children class.

One of the problem in Karonese was the using of Karonese language. Some of the students of Sunday School was hard to speak Karonese language meanwhile it was their mother tough. They are more able to speak Indonesian than Karonese. The 
reason why they are able speak Bahasa Indonesia than Karonese because their parents seldom use Karonese at home. Second reasons some of their parents was married with cross culture. For example Karonese with Toba, Karonese with Chinese or Karonese with Tapsel. Those reasons are the background why Karonese was seldom use Karonese language at home. Generally, church gives the solution for them to learn Karonese language, but it is vise versa. The Indonesia language is the language for children when they worship at church.

From the background of the prevoius problem above the researchers tried to give students the story from the bible. Ususally, they love the bible story. Here the researchers gave story of David and Goliath, David and Yonathan and The Born of Jesus. The researcher toke the story from the bible and compiled it into two languages. They were Karonese and English. These activity has run for six months. She had made a short film about The Born of Jesus into two languages. They were Karonese and English.

The activity was run into two cycles. Before the researcher run the cycle she gave the learning and theories of basic grammar and vocabulary. Of course it was very important for them because the students should be known the meaning of the story or they understood what was the story talking about. After the researcher gave te theory so the researcher gave the story from the bible. Here the researcher was introducing the characters first to the students. Not only the characters but also the plot, climax and resolution of the story. Of course the researcher taught it more simple to the students. To know was the story was understood by students so the researcher gave some questions from the story and the last the researcher asked them to retell the story in front of the class. This atmosphere was the backround of researcher using storytelling to improve their learning English and Karonese.

Storytelling is one technique that usually used by a teacher to persuade the students to learn a language. The readers could find many story In Bahasa Indonesia text book. It could tell a fable or tale story. Not only Bahasa Indonesia text book that ofer the story but also English Text Book has given many story based on narative text. The story that have availabe on this book gave feed back in reading a language.

There were some prevoius researchers that have used this techiuge. First was Inayah Ratih (2015), on her title research was "Improving Students' Speaking Skill Trough Storytelling Technique". She found that the storytelling technique could help them to improve their speaking ability. The second researchers was Fikriyah (2016), on her title research " Using the Storytelling Technique to Improve English Speaking Skills of Primary Students". She found that based on the responses to the questionnaire, $80 \%$ of the students responded positively to the implementation of the treatment. These 
results indicate that this classroom action research was a success where Storytelling Technique effectively improved the students' English-speaking skills".

The problem of the research was that storytelling could improve students in learning Karonese and English language.

\section{Literature Review}

The history of storytelling was introducing from Australian Aboriginal. They printed symbols from stories on cave walls as a means of helping the storyteller remember the story then it told using combination of oral narrative, music, rock art and dance, which bring understanding and meaning of human existence through the stories. Time went away; storytelling was developing into modern era. Some authors had divided it into fable, fairytales, folktales, mythology, and legends, Wikipedia. Below was definition of storytelling from the experts.

Storytelling is the comunicating with words and sound. It is an art expression and improvisation which revolves around a plot and/or narrative point of view, Coconi (2013). Maynard (2005) defined stories as the way people communicate their experience, the way they understand the experience of others, the way they liberate their imaginations, the way they make sense of the world and their own position within it. Maynard (2005) stated that stories are important to people, politics, and education. Stories are how people make sense of themselves and their worlds.

Storytelling is an important part of being human. Stories connect us to each other; they create a bond. We all love to hear stories, but can we tell them? Whether you are a business professional giving a presentation, or a simple lover of stories, Lisa (2018). Here the storyteller should able to tell well the story to the listener. In doing this research the researcher not only teach how become a good storyteller but also could solve the problem in teaching English.

Diane (2010) states four problem solving in teaching English. They are (1) Define exactly why a student is experiencing difficulty in the classroom. (2) Analyze potential problems by identifying the variables that may. (3) contribute to a student's difficulties, including classroom instruction. (4) Develop and implement a plan to address these issues and Evaluate the plan over a series of weeks and modify the plan when necesarry.

The researcher summary the story into Theme, Characters, Plot, Setting and Bodylanguage. Below the description of the storytelling performance. 
TABLE 1: Storytelling Description.

\begin{tabular}{|c|c|c|c|}
\hline Identify & Description English & Description Karonese & Score \\
\hline Theme & Trust with God & Tek man Dibata & 5 \\
\hline Characters & David and Goliath & Daud ras Goliat & 5 \\
\hline Plot & $\begin{array}{l}\text { Goliath was a nine-foot-tall soldier } \\
\text { from Gath. He bragged that he could } \\
\text { beat any Israelite soldier who would } \\
\text { fight him. But all the Israelite } \\
\text { soldiers were afraid to fight him. } \\
\text { David was a young shepherd boy } \\
\text { who believed in God. He said, "The } \\
\text { Lord who delivered me from the } \\
\text { paw of the lion and from the paw of } \\
\text { the bear, will deliver me from the } \\
\text { hand of this Philistine." David took } \\
\text { his sling and five smooth stones } \\
\text { from the brook. Then he went to } \\
\text { fight Goliath. } \\
\text { King Saul wanted to put his heavy } \\
\text { armor and helmet on David. He also } \\
\text { tried to give David a big sword, but } \\
\text { David said he could not wear them. } \\
\text { He knew that his strength and } \\
\text { protection came from God. } \\
\text { Goliath cursed the boy coming out } \\
\text { to fight him. David said to the } \\
\text { Philistine, "You come against me } \\
\text { with sword and spear and javelin; } \\
\text { but I come against you in the name } \\
\text { of the Lord Almighty, the God of the } \\
\text { armies of Israel, whom you have } \\
\text { defied." } \\
\text { David threw a stone with his sling at } \\
\text { Goliath. It hit Goliath in the forehead } \\
\text { and the giant fell face down. } \\
\text { Without a sword in his hand he } \\
\text { struck down the giant and killed } \\
\text { him. } \\
\text { David believed in God, and God } \\
\text { helped him win over the giant. }\end{array}$ & $\begin{array}{l}\text { Goliat tentara si seh galangna reh } \\
\text { arah Gat. Ia tek kel adi ia danci } \\
\text { naluken tentara Israel si ngelawan ia. } \\
\text { Tapina kerina tentara Israel labo } \\
\text { pang ngelawan ia. } \\
\text { Daud e me kap si permakan si tek kel } \\
\text { man Dibata. Katakenna man Dibata " } \\
\text { Dibata kap sinaruhken aku } \\
\text { ngelawawan Singa arah cakarna nari, } \\
\text { maka la ka nge naruhken aku } \\
\text { ngelawan Bangsa Filistin enda." } \\
\text { Buatna ketapel ras lima batu. } \\
\text { Ayunken Daud batundai. I baba Daud } \\
\text { guna erperang ngelawan Goliat. } \\
\text { Raja Saul reh mbaba baju perang ras } \\
\text { helem man Daud. Breken Raja Saul } \\
\text { ka pedang man Daud, tapi Daud labo } \\
\text { lit make baju ras pe pedang. I teh } \\
\text { Daud Dibata kap sinjaga ia. } \\
\text { Nina Daud ku Goliat, Engko reh ku } \\
\text { aku ras pedang tombak, tapi aku reh } \\
\text { mababa gelar Dibataku. } \\
\text { I benter Daud batu ku Goliat. Ndabuh } \\
\text { Goliat kerna batu e kena ku takaln } \\
\text { ras reh Daud mbunuh Goliat. } \\
\text { Daud tek mn Dibata, Dibata kap } \\
\text { sinampati Daud ngelawan raksasa } \\
\text { Goliat. }\end{array}$ & 20 \\
\hline Setting & Israel and Philistine & & 5 \\
\hline Bodylanguage & $\begin{array}{l}\text { Use Media and move the body } \\
\text { based on the thone and character }\end{array}$ & & 15 \\
\hline
\end{tabular}

\section{Research Method}

This study was using Classroom Action Research (CAR). Classroom Action Research was utilized because it aimed to improve outcomes of teaching and learning. It helped the researcher be more aware of the process. Moreover, the process in this research 
was continuous and cyclical. Classroom action research was portrayed as a cyclical or spiral process involving steps of planning, acting, observing, and reflecting with each of these activities being systematically and self critically implemented and interrelated. Therefore it should be done by teacher/researcher on the classroom.

CAR could help the researcher in doing this research. From this method the researcher would know the improving students in storytelling. Of course this method would trough the process of planning of the material, acting of the implementation of the material and students, observing the material after the istrument giving and the last was the reflecting of the material. Usually the reseracher said it was the evaluation of the material.

This study applied two cycles by implementing the four steps, planning, action, observation and reflection is shown in the following:

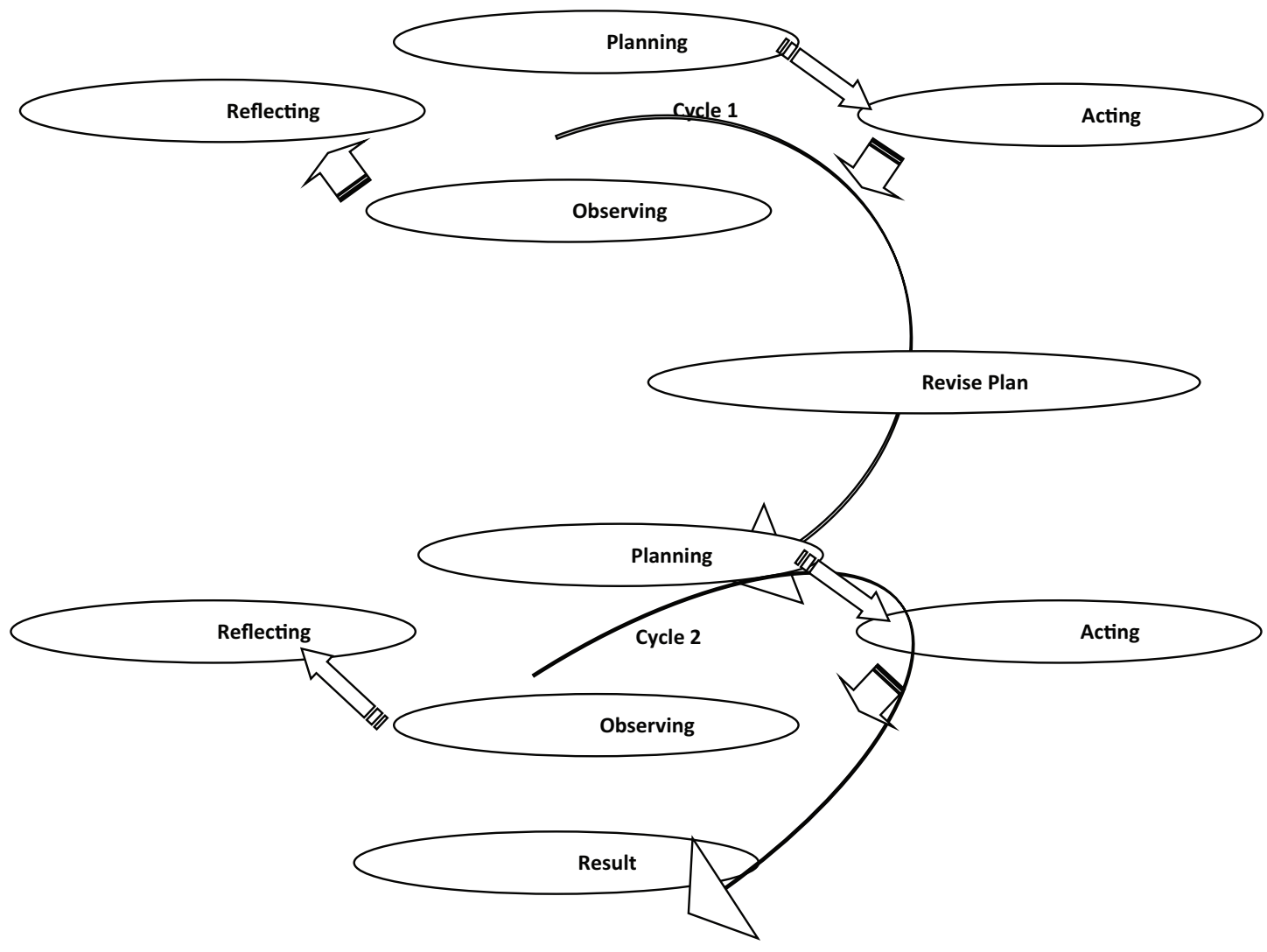

Figure 1: Simple Action Research Model (Mcissac: 1995).

The subject of this study is the students of Sunday school at GBKP. It consisted of 20 students. To collect the data of this research the researcher used the instruments. There were:

(a) Speaking test was used to assess the students' in learning Karonese and English Language. 
(b) Observation sheet was prepared to investigate the situation and the problems found during the teaching and learning process.

(c) Questionnaire sheet was used to know students' opinion about Karonese and English storytelling.

(d) Diary note was written to note personal evaluation about the situation of the class while teaching-learning process related to progression achieved.

The procedure of collecting data was performed by administrating fourteen meeting for two cycles where one meeting, six meetings belong to the first cycles and seven others meeting belong to the second cycles. Each cycle involved planning, action, observation, and reflection.

\section{Discussion}

The researchers did the score of storytelling participation. There were 20 students who toke as a sample. The researcher did two cycles in doing these research. She found 18 students who improve the English storytelling and 15 students who improve in Karonese storytelling. It meant that there were 2 students who did not improve English storytelling and 5 students who did not improve their Karonese storytelling. Below was the scoring of the storytelling test.

From the table above was gotten two cycles. In the cycle one was gotten there were 11 students got below 70 in English Storytelling and 10 students got below 70 in Karonese storytelling. it means that only 9 students who got the score above 70 in English storytelling and 10 students who got the score above 70 . It meant 55\% who improve the English storytelling and 50\% who improve in Karonese storytelling.

Because of the score was not satisfy so the researchers did cycle 2 activity and it got there were 13 students who got score above 70 in English storytelling and 7 students who got score above 70 Karonese storytelling.

\section{Conclusion}

After analyzing the data, it was found out that the students' English and Karonese Learning score improved from cycle I until cycle II. It is shown from the improvement of the mean score from the first test (cycle I), and the last meeting (cycle II). The students' score continuously improved in ea test. From the improvement, and also from the students' attention in teaching learning process it can be concluded that storytelling can 
TABLE 2: Scoring Improvement of English and Karonese Storytelling in Cycle 1 and Cycle 2.

\begin{tabular}{|c|c|c|c|c|c|}
\hline \multirow[t]{2}{*}{ No. } & \multirow[t]{2}{*}{ Students' Name } & \multicolumn{2}{|c|}{ Cycle 1} & \multicolumn{2}{|c|}{ Cycle 2} \\
\hline & & $\begin{array}{l}\text { English } \\
\text { Language }\end{array}$ & $\begin{array}{l}\text { Karonese } \\
\text { Language }\end{array}$ & $\begin{array}{l}\text { English } \\
\text { Language }\end{array}$ & $\begin{array}{l}\text { Karonese } \\
\text { Language }\end{array}$ \\
\hline 1 & $\begin{array}{l}\text { Revindo } \\
\text { Sembiring }\end{array}$ & 70 & 70 & 78 & 80 \\
\hline 2 & Mario Pinem & 80 & 80 & 86 & 88 \\
\hline 3 & Marcel Pinem & 70 & 60 & 76 & 80 \\
\hline 4 & Jejo Tarigan & 68 & 50 & 68 & 55 \\
\hline 5 & Axelo Sembiring & 70 & 55 & 75 & 80 \\
\hline 6 & Arthur Sembiring & 60 & 60 & 65 & 75 \\
\hline 7 & Glory Вг. Ginting & 85 & 80 & 88 & 89 \\
\hline 8 & Joice Вr. Ginting & 65 & 60 & 70 & 67 \\
\hline 9 & Yona Br. Ginting & 84 & 80 & 85 & 88 \\
\hline 10 & Grace Br. Ginting & 60 & 55 & 60 & 80 \\
\hline 11 & $\begin{array}{l}\text { Rivana Br. } \\
\text { Sembiring }\end{array}$ & 65 & 60 & 70 & 50 \\
\hline 12 & $\begin{array}{l}\text { Kenly Br. } \\
\text { Sinulingga }\end{array}$ & 65 & 60 & 70 & 80 \\
\hline 13 & $\begin{array}{l}\text { Angel Br. } \\
\text { Brahmana }\end{array}$ & 70 & 75 & 70 & 80 \\
\hline 14 & Echa Вг. Pinem & 70 & 76 & 70 & 75 \\
\hline 15 & Chery Br. Lubis & 68 & 70 & 66 & 75 \\
\hline 16 & Feber Вr. Pinem & 70 & 80 & 75 & 80 \\
\hline 17 & Jose Tarigan & 60 & 65 & 70 & 66 \\
\hline 18 & Grace Br. Surbakti & 65 & 50 & 65 & 50 \\
\hline 19 & Theo Kaban & 20 & 70 & 40 & 70 \\
\hline 20 & Denis Kaban & 20 & 70 & 30 & 70 \\
\hline
\end{tabular}

improve students' achievement in learning. The students were enthusiastic in learning English and Karonese storytelling encourage their creativity and ideas to speak better.

\section{Acknowledgements}

The researcher gave thanks to all the persons who has supported and motivated this research. Expecially the Sunday School Students of GBKP Jalan Mekatani Marindal Kecamatan Patumbak. The researcher also give thanks to the all committes and reviewers of Annual International Conference on Language and Literature (AICLL) 2018 who has gave me a change to present my reserach writing. Hopefully this research can be useful to the readers. 


\section{References}

[1] Coconi, A. (2013). [Online] Available http://www.ehow.com/info_8771474_typesstorytelling.html [ June 11 2014]

[2] Fikriyah. (2016). Using the Storytelling Technique to Improve English Speaking Skills of Primary Students. English Educational Journal. Vol. 7. No. 1. Universitas Syiah Kuala.

[3] Haager Diane, Klingner Janette, Acheves Terese C. (2010). How to Teach English Language Learners. United States Jossey Bass Teacher.

[4] Inayah Ratih. (2015). Improving Students' Speaking Skill Trough Storytelling Technique (An Experimental Study in a Senior High School in Bandung). Journal of English Longuage Teaching in Indonesia. Vol.3. No.1. STKIP Siliwangi.

[5] Lisa. (2018) [Online] Thibert. Available https://www.educatall.com/page/683/ Different-methods-for-storytelling.html. 22 February 2018. 22:25

[6] Maynard. B. (2005). The Importance of Story. Available in http://subversiveinfluence.com/2005/01/the-importance-of-story/[June 12 2014]

[7] _. Storytelling. Retrieved from Wikipedia https://en.wikipedia.org/ wiki/Storytelling on January 2018. 